\title{
Methylxanthines and the Kidney
}

\author{
Hartmut Osswald ${ }^{2}$ and Jürgen Schnermann ${ }^{1}$ \\ ${ }^{1}$ National Institute of Diabetes and Digestive and Kidney Diseases, National Institutes of Health, \\ Bethesda, Maryland 20892 \\ ${ }^{2}$ Department of Pharmacology and Toxicology, University of Tübingen, Tübingen, Germany
}

\section{Introduction}

The plant constituents caffeine and theophylline have been known to alter kidney function since the demonstration in 1864 that caffeine can increase urine production in patients with congestive heart failure and edema (Koschlakoff 1864). Interest in the renal actions of methylxanthines has remained acute although the clinical use of theophylline is largely restricted to the treatment of extra-renal diseases such as asthma. The focus of this chapter is a description of the renal effects of the natural methylxanthines, mainly of caffeine and theophylline, and a discussion of current understanding of the mechanisms underlying these effects. Important progress in mechanistic thinking has been made by using modified methylxanthines, and it will therefore sometimes be necessary to include data obtained with synthetic xanthine derivatives when this permits discrimination between the different targets of the natural compounds. This is especially relevant in the case of methylxanthines as antagonists of adenosine receptors, a predominant mechanism in many renal actions of methylxanthines. Nevertheless, a broad discussion of adenosine and its interaction with adenosine receptors is not the goal of this review, and adenosine will only be discussed in the context of understanding methylxanthine actions. We also will make reference to nonnatural xanthine compounds in cases where their actions are in conflict with those of caffeine or theophylline or where they shed light on likely mechanisms of action.

\section{Diuresis}

The natural methylxanthines caffeine and theophylline were used traditionally to increase urine output until more potent diuretics became available in the middle of the last century. In numerous studies in animal and humans the order of diuretic potency of the natural methylxanthines was found to be theophylline $>$ caffeine $>$ paraxanthine $>$ theobromine. The actions of methylxanthines as diuretics have been extensively reviewed in an excellent chapter in the Handbook of Experimental Pharmacology in which the literature prior to 1970 has been summarized and discussed in full detail (Fülgraff 1969). In the period since it has been confirmed repeatedly that caffeine and other methylxanthines can induce an increase in urine flow in humans and experimental animals. The dose of caffeine that elicits a significant acute diuresis has been reported to be in the order of $300 \mathrm{mg}$, the equivalent of about 4-5 cups of coffee (Grandjean et al. 2000; Passmore et al. 1987; Riesenhuber et al. 2006). As determined by impedance analysis, an acute intake of $642 \mathrm{mg}$ of caffeine without

For Correspondence: Jurgen Schnermann, MD., National Institute of Diabetes and Digestive and Kidney Diseases, National Institutes of Health, Building 10, Room 4D51, 10 Center Drive-MSC 1370, Bethesda. MD 20892, USA, (Tel) 1-301-435-6580, (Fax) 1-301-435-6587,jurgens@intra.niddk.nih.gov.

Dr. Hartmut Osswald, em. Professor of Pharmacology, Department of Pharmacology and Toxicology, Faculty of Medicine, University of Tübingen, Wilhelmstrasse 56, D-72074 Tübingen, Germany

Jürgen Schnermann, M.D., Senior Investigator, Chief, Kidney Disease Branch, NIH/NIDDK, Bldg. 10, Room 4D51, 10 Center Drive - MSC 1370, Bethesda, MD 20892, U.S.A. 
a change in total fluid intake caused a measurable decrease in body weight corresponding to a $2.7 \%$ reduction of total body water (Neuhauser et al. 1997). Furthermore, a positive fluid balance prior to methylxanthine administration enhanced the diuretic efficacy of methylxanthines, while a negative fluid balance reduced the diuretic response (Fülgraff 1969). The diuretic potency of caffeine appears to be also modulated by age and habituation, with old age and previous exposure to caffeine causing further decreases in the diuretic effectiveness of caffeine (Izzo et al. 1983).

Overall, the relatively modest potency of caffeine to enhance water excretion and cause net water loss is consistent with studies in which caffeine (up to $6 \mathrm{mg} / \mathrm{kg}$ ) given for 11 days did not affect 24-hour urine volume and was not associated with symptoms of negative fluid balance (Armstrong et al. 2005). The same conclusion was drawn in a study where the diuretic effects of caffeinated and non-caffeinated electrolyte drinks were compared at rest and during moderate exercise (Wemple et al. 1997). While the ingestion of caffeine ( $25 \mathrm{mg} /$ $\mathrm{dl}$ at $35 \mathrm{ml} / \mathrm{kg}$ ) caused a higher urine flow at rest compared to caffeine-free fluid, urine flow was reduced to the same level during exercise and this was associated with identical increments of plasma catecholamine concentrations. In a smaller study, consumption of tea as the major fluid source did not cause noticeable differences in hydration status compared to non-tea fluid intake in a group of mountaineers at high altitude (Scott et al. 2004). Thus, the general advice against using caffeinated drinks for volume replacement may need to be qualified in that beverages containing moderate amounts of caffeine do not appear to cause significant fluid losses (Armstrong 2002).

Caffeine in high concentration supplied in a Ca-free medium has been shown to prevent the $\mathrm{Ca}$ increase caused by vasopressin in rat renal papillary collecting duct cells and this may blunt the increase of cAMP and the effect of vasopressin on water permeability (Ishikawa et al. 1992). Caffeine appears to exert this effect by depletion of endoplasmatic Ca stores suggesting that its action may be caused by interaction with ryanodine sensitive Ca release channels. Nevertheless, there is no evidence in support of the notion that methylxanthines in lower concentrations inhibit solute-free water absorption in the distal part of the nephron. In fact, theophylline has been observed to mimick the effect of vasopressin on water permeability in isolated perfused collecting ducts and in the bladder of the toad (Grantham and Orloff 1968; Orloff and Handler 1962). Both vasopressin and theophylline increased cellular cAMP levels indicating that the theophylline effects are mediated by inhibition of phosphodiesterase (Handler et al. 1965). Caffeine is unlikely to reduce collecting duct water reabsorption through inhibition of adenosine receptors since in perfused and non-perfused collecting ducts adenosine has been shown to inhibit AVP-stimulated water permeability through activation of A1 adenosine receptors (Edwards and Spielman 1994; Yagil 1990). Since A2 adenosine receptor-mediated effects have not been identified (Edwards and Spielman 1994; Yagil 1990), caffeine would thus be expected to enhance, not inhibit collecting duct water transport, just as inhibition of cAMP degradation by possible methylxanthine effects on PDE would not be predicted to inhibit water transport. Furthermore, there does not seem to be a direct effect of caffeine on vasopressin secretion since plasma vasopressin levels have been reported to be unaltered after caffeine ingestion (Izzo et al. 1983; Nussberger et al. 1990). One would conclude that the type of diuresis caused by methylxanthines is mostly or exclusively a solute diuresis.

\section{Natriuresis}

Increased urine flow caused by methylxanthines is accompanied by increased excretion of sodium, chloride, calcium, phosphate, magnesium and other urinary solutes. Although methylxanthines have in some studies been found to increase the tubular $\mathrm{Na}$ load, significant natriuresis can occur without changes in GFR or renal blood flow clearly indicating that the 
natriuresis caused by methylxanthines is predominantly the result of inhibition of tubular salt transport (Davis and Shock 1949; Ludens et al. 1970; Shirley et al. 2002). Natriuresis without hemodynamic changes was also caused by methylxanthines in premature infants and newborn rabbits (Gouyon and Guignard 1987; Mazkereth et al. 1997). The increased excretion of calcium caused by caffeine may have implications for calcium homeostasis. Abstinence from moderate daily caffeine consumption ( $200 \mathrm{mg}$ or less) has been noted to significantly increase plasma concentrations of ionized calcium and to reduce PTH levels in women on a relatively low dietary calcium intake (Massey et al. 1994; Wise et al. 1996).

In addition to causing natriuresis and diuresis, the administration of theophylline to conscious rats $(10-50 \mathrm{mg} / \mathrm{kg}$ oral) or anesthetized rabbits $(15 \mathrm{mg} / \mathrm{kg}$ i.v. $)$ was accompanied by increased urinary excretion of PGE2 and cAMP (Baer et al. 1983; Oliw et al. 1977). Pretreatment with indomethacin or meclofenamate prevented the natriuretic action of theophylline, and conversely, theophylline caused a transient reversal of the antinatriuresis and antidiuresis elicited by indomethacin in patients with rheumatic diseases (Oliw et al. 1977; Seideman et al. 1987). The possibility that some effects of methylxanthines on urine excretion could be indirect is also supported by the observation that plasma and kidney atrial natriuretic factor activity increased following prolonged caffeine ingestion (Eggertsen et al. 1993; Lee et al. 2002). Nevertheless, no change in plasma ANF was seen 2 hours after an oral intake of a single $250 \mathrm{mg}$ dose of caffeine (Nussberger et al. 1990). That the natriuretic effect of methylxanthines is probably not strictly dependent on ANF is also suggested by the observation that prior exposure to theophylline did not modify the natriuretic action of ANF (Beutler et al. 1990).

There is considerable evidence to indicate that methylxanthine-induced natriuresis is predominantly a consequence of inhibition of salt transport along the proximal convoluted tubule. Administration of $400 \mathrm{mg}$ of caffeine to healthy human subjects caused an about 1.5 fold increase in $\mathrm{Na}$ excretion and this was associated with an increase in the clearance of lithium (Shirley et al. 2002). A reduction of proximal solute reabsorption in humans as assessed by lithium clearance was also caused by theophylline and aminophylline (Beutler et al. 1990; Brater et al. 1983). At the level of the single tubule, systemic administration of theophylline $(20 \mathrm{mg} / \mathrm{kg}$ s.c.) caused an about $20 \%$ reduction in proximal tubular reabsorptive capacity as determined with the split-droplet technique in the rat (Fülgraff 1969). Tubular microperfusion of the loop of Henle with solutions containing theophylline or IBMX did not significantly alter $\mathrm{Cl}$ reabsorption indicating that methylxanthines do not affect salt absorption along proximal straight tubules and thick ascending limbs (Schnermann et al. 1977). The effect of methylxanthines on Na transport in tubular segments beyond the proximal tubule and the loop of Henle has not been explored in detail although on the basis of indirect evidence an inhibitory action in more distal parts of the tubule has been proposed (Brater et al. 1983; Shirley et al. 2002).

The mechanism by which methylxanthines inhibit proximal $\mathrm{NaCl}$ reabsorption is related to their properties as antagonists of adenosine receptors. Xanthine derivatives such as doxofylline or enprofylline with low affinity for adenosine receptors, but similar ability to inhibit PDE, have been noted to exert only marginal effects on natriuresis compared to aminophylline or theophylline suggesting that inhibition of adenosine receptors is critical for the natriuretic action (Andersson et al. 1984; Cirillo et al. 1989; Franzone et al. 1988).

Strong experimental evidence indicates that it is the A1 adenosine receptor subtype whose inhibition results in natriuresis. In mice with targeted deletion of A1 adenosine receptors, the diuretic and natriuretic effect of caffeine $(45 \mathrm{mg} / \mathrm{kg})$ or theophylline $(45 \mathrm{mg} / \mathrm{kg})$ was entirely absent (Rieg et al. 2005). The natriuresis caused by systemic administration of xanthine derivatives designed to selectively inhibit A1 adenosine receptors such as CVT-124, DPCPX, or KW-3902 has been shown by lithium clearance and renal tubular micropuncture 
approaches to be accompanied by inhibition of proximal tubular fluid reabsorption (Knight et al. 1993; Kost et al. 2000; Mizumoto and Karasawa 1993; Wilcox et al. 1999). DPCPXinduced natriuresis can be prevented by pertussis toxin, consistent with an involvement of the Gi-coupled A1 adenosine receptors (Kost et al. 2000).

In view of the dominant role of $\mathrm{Na} / \mathrm{H}$ exchange for $\mathrm{Na}$ reabsorption in the proximal tubule it is not surprising that modulation of NHE3 has been implicated in adenosine-dependent modulation of Na reabsorption. In opossum kidney cells low concentrations of an A1 adenosine receptor agonist $\left(<10^{-8} \mathrm{M}\right)$ do in fact activate NHE3, an effect that is blocked by A1 adenosine receptor antagonists and apparently mediated by inactivation of adenylyl cyclase (Di Sole et al. 2003). Downregulation of NHE3 and of alpha1/beta1-NaKATPase protein expression was observed following a 1 day treatment with caffeine in rats (Lee et al. 2002). On the other hand, theophylline ( $1 \mathrm{mM}$ ) did not affect $\mathrm{HCO}_{3}$ flux as assessed from the $\mathrm{pH}$ recovery in stationary microperfusion studies in the rat (Bailey 2004). In renal proximal tubular cell cultures and opossum kidney cells A1 adenosine receptor activation stimulated and inhibition of A1 adenosine receptors by DPCPX or KW-3902 inhibited apical Na/Pi (Cai et al. 1994; Cai et al. 1995; Coulson et al. 1991) and Na/glucose cotransport (Coulson et al. 1991; Coulson et al. 1996). Inhibition of Pi uptake by A1 adenosine receptor antagonists was associated with a dose-dependent increase of cellular cAMP production as well as an increase in PKC activity (Cai et al. 1995; Coulson et al. 1991; Coulson et al. 1996). Theophylline and A1 adenosine receptor- selective xanthine derivatives inhibited basolateral $\mathrm{HCO}_{3}$ conductance in microperfused rabbit proximal convoluted tubules and this effect was mimicked by forskolin and chlorophenylthio-cAMP suggesting that methylxanthines inhibit $\mathrm{Na} / \mathrm{HCO}_{3}$ cotransport activity by increasing intracellular cAMP (Takeda et al. 1993). To the extent that caffeine causes an increase in arterial blood pressure, a potential direct role of blood pressure in inhibiting tubular reabsorption and altering NHE3 distribution needs to be considered (Nussberger et al. 1990; Rachima-Maoz et al. 1998; Rakic et al. 1999). Finally, it should be pointed out that administration of methylxanthines only explores the impact of a reduction in adenosinemediated effects, and that the consistent stimulatory effect of adenosine suggested by this intervention is therefore not in conflict with the possibility that high concentrations of adenosine may elicit inhibition of proximal tubular transport (Di Sole 2008; Di Sole et al. 2003).

\section{Hemodynamics}

Several studies in anesthetized dogs agree that the intrarenal infusion of methylxanthines does not affect renal blood flow significantly although renal vascular tone may decrease slightly because of small blood pressure reductions (Ibarrola et al. 1991; Osswald 1975; Premen et al. 1985). Furthermore, theophylline or caffeine do not alter renal plasma flow in humans to an extent that could be detected by clearance techniques (Beutler et al. 1990; Brater et al. 1983; Brown et al. 1993; Passmore et al. 1987). Changes of glomerular filtration rate (GFR) in response to methylxanthines are sometimes more pronounced than those of RBF causing increases of filtration fraction (Fulgraff 1969). On the other hand, theophylline consistently inhibited adenosine-induced reductions of GFR and RBF in dogs and rats (Osswald 1975; Osswald et al. 1977; Pawlowska et al. 1987; Spielman 1984). Similarly, the vasodilator response of medullary blood flow to adenosine was blocked by 8 phenyltheophylline (Dinour and Brezis 1991). Thus, methylxanthines can affect renal hemodynamics by blocking the vascular actions of adenosine, at last in the range of supranormal adenosine levels. The absence of major effects of methylxanthines on renal hemodynamics could be due to low resting levels of adenosine. However, this seems unlike since renal interstitial adenosine levels as determined by microdialysis are in the order of $50-200 \mathrm{nM}$, a range in which both A1AR and A2aAR should be partially occupied 
(Baranowski and Westenfelder 1994; Nishiyama et al. 2001; Siragy and Linden 1996; Zou et al. 1999). Thus, renal vascular tone under basal conditions appears to represent a state of balanced activation of A1 and A2a adenosine receptors. Vascular actions of theophylline could also result from a reduction of the inhibitory effect of adenosine on catecholamine release from renal sympathetic nerve terminals (Hedqvist and Fredholm 1976). In isolated perfused rabbit kidneys, theophylline did not affect norepinephrine release or renal blood flow under basal conditions, presumably a reflection of the absence of a basal sympathetic tone (Hedqvist et al. 1978). However, the increased norepinephrine release following renal nerve stimulation was slightly potentiated by theophylline, and this was accompanied by a decrease in the vasoconstrictor response to nerve stimulation (Hedqvist et al. 1978).

Similarly, theophylline attenuated the vasoconstrictor response to exogenous norepinephrine (Hedqvist et al. 1978; Yoneda et al. 1990). Finally, the reduction of GFR following dipyridamole and indomethacin administration in rheumatic patients was fully reversed by theophylline suggesting that some of the vascular effects of indomethacin may be adenosine-mediated (Seideman et al. 1987).

In contrast to the negligible effects of methylxanthines on global renal vascular tone, theophylline has been found to fully inhibit the local tubuloglomerular feedback (TGF) response to changes of $\mathrm{NaCl}$ concentration in individual nephrons. Intratubular and intravenous administration of theophylline or PSPX caused a dose-dependent blockade of the afferent arteriolar constriction induced by increases in $\mathrm{NaCl}$ concentration in the tubular fluid passing the macula densa segment (Franco et al. 1989; Osswald et al. 1980; Schnermann et al. 1977). This effect is the result of inhibition of A1 adenosine receptors since the effect of theophylline on TGF was fully mimicked by subtype specific adenosine receptor antagonists (Kawabata et al. 1998; Ren et al. 2002; Schnermann et al. 1990; Thomson et al. 2000; Wilcox et al. 1999). Infusion of hypertonic saline (HS) into the renal artery of anesthetized dogs has been shown to cause sustained vasoconstriction, and this has been considered a model of "whole kidney tubuloglomerular feedback" (Gerkens et al. 1983). Like single nephron TGF, vasoconstriction caused by hypertonic saline was inhibited by theophylline or aminophylline (Gerber and Nies 1986; Gerkens et al. 1983). Extracellular conversion of released cAMP by ecto-phosphodiesterases and 5'-nucleotidase has been suggested to constitute a significant source of adenosine in the kidney (Jackson et al. 1997). Thus, the phosphodiesterase-inhibitory effects of xanthines may contribute to inhibition of TGF by reducing the interstitial adenosine levels (Mi et al. 1994).

\section{Renin Secretion}

It is remarkable that methylxanthines are able to cause natriuresis despite the fact that they also stimulate the strongly antinatriuretic renin-angiotensin system. Theophylline increased plasma renin activity in dogs, and this increase was shown to occur without changes in blood pressure or in the plasma levels of epinephrine and norepinephrine indicating that it was not mediated by the renal baroreceptor mechanism or by adrenergic receptors (Reid et al. 1972). In fact, theophylline stimulated renin release even in dogs treated with propranolol. Likewise, oral administration of caffeine in rats for 10 days was associated with a marked rise of renin secretion (Tofovic and Jackson 1999). Even though it was thought that the theophylline effect may be mediated by inhibition of PDE and the resulting increase in cellular cAMP (Reid et al. 1972) it now seems likely that stimulation of renin by methylxanthines is at least in part, but probably predominantly a consequence of inhibition of adenosine receptors. Inhibition of A1AR by the selective antagonist FK-453 caused a significant increase of plasma renin (Balakrishnan et al. 1993), and DPCPX partially inhibited the stimulation of renin release caused by low $\mathrm{NaCl}$ in a microperfused JGA preparation (Weihprecht et al. 1990). Furthermore, infusion of caffeine or theophylline at a dose that did not change renal cortical cAMP has been reported to abolish the inhibitory 
effect of intrarenally infused adenosine on renin secretion, and this effect could be dissociated from hemodynamic changes (Arend et al. 1987; Choi et al. 1993; Spielman 1984). In support of the notion that endogenous adenosine exerts a general inhibitory "brake" function in renin release, caffeine or theophylline as well as specific A1AR antagonistic xanthines have been reported to augment the renin-stimulatory effects of a low renal artery pressure, a low $\mathrm{Na}$ diet, furosemide, isoproterenol, and of vasodilators like diazoxide or hydralazine (Brown et al. 1991; Langard et al. 1983; Paul et al. 1989; Pfeifer et al. 1995; Tofovic et al. 1991; Tseng et al. 1993). Despite the convincing effect of methylxanthines in experimental animals, studies in normotensive human subjects examining the effect of caffeine $(250 \mathrm{mg}$ ) or coffee drinking have reported plasma renin concentration to increase, decrease, or remain unchanged indicating that caffeine in moderate doses may not consistently induce the plasma caffeine levels needed to stimulate renin release (Nussberger et al. 1990; Robertson et al. 1978; Smits et al. 1983). Similarly, no increases of plasma renin were observed in response to caffeine or coffee drinking in hypertensive patients (Eggertsen et al. 1993; Palatini et al. 1996; Robertson et al. 1984) or in patients with autonomic failure (Onrot et al. 1985).

\section{Disease and Therapeutic Aspects}

\section{Polycystic Kidney Disease}

Generation of cAMP has been shown to play a role in the secretion of fluid that is thought to be partly responsible for the accumulation of fluid in renal cystic disease (Belibi et al. 2002). Thus, by augmenting cAMP levels methylxanthines could contribute to the progression of cyst formation. In fact, in primary cultures of renal cysts from patients with autosomal dominant polycystic kidney disease (ADPKD), caffeine (10-1000 $\mu \mathrm{M})$ increased levels of cellular cAMP and this was associated with an increase of transepithelial chloride secretion. Furthermore, caffeine greatly potentiated the augmentation of cAMP induced by Gs-coupled agonists like vasopressin and PGE2. The increase of cAMP by caffeine was in part mediated by inhibition of PDE since rolipram, a PDE inhibitor that does not interact with adenosine receptors, also caused a marked elevation of cAMP. However, an elevation in cAMP was also seen with adenosine $(10 \mathrm{mM})$, and this effect was attenuated, but not fully blocked by caffeine suggesting that stimulation of A2 adenosine receptors contributed to the accumulation of cAMP in cyst cells (Belibi et al. 2002). Cyst formation has also been related to impaired mechanosensation by primary cilia since both polycystin 1 (PC1) and polycystin 2 (PC2) are found in association with cilia. In fact, the increase in cytosolic Ca caused by a flow stimulus in renal cells of wild type mice was not seen in cells from PC1- or PC2deficient mice or after treatment of wild type cells with blocking antibodies against PC2 (Nauli et al. 2003). The increase in cytosolic Ca by flow was blocked by high concentrations of caffeine suggesting that it was caused by release of stored $\mathrm{Ca}$ across ryanodine sensitive receptors in response to an initial Ca entry through PC2 cation channels. Nevertheless, caffeine ingestion did not accelerate cyst formation in the Han:Sprague Dawley rat model of ADPKD although it was associated with the generation of hypertension (Tanner and Tanner 2001).

\section{Nephropathies}

In several experimental disease models, chronic caffeine administration has been found to exacerbate the development of hypertension and renal disease, perhaps through the effect of caffeine on renin secretion. For example, the presence of caffeine $(0.1 \%)$ in the drinking water augmented the blood pressure increase caused by renal arterial constriction and this was associated with a greater increase of plasma renin concentration (Choi et al. 1993; Kost et al. 1994; Ohnishi et al. 1986). Similarly, a 10 day caffeine exposure enhanced renin secretion to a markedly greater extent in spontaneously hypertensive heart failure (SHHF/ 
Mcc-fa) rats than in control rats (Tofovic et al. 1999). In association with the increase of renin secretion, prolonged caffeine ingestion caused a faster decline of renal function and a significant enhancement of urinary protein excretion (Tofovic and Jackson 1999). An adverse effect of chronic caffeine intake on renal function was also observed in puromycin aminonucleoside-induced nephrosis in rats. Both the decline of renal function assessed as creatinine clearance and the increase of renin secretion were enhanced in puromycin-treated rats receiving caffeine in comparison to nephrotic rats receiving tap water (Tofovic et al. 2000). In addition, caffeine potentiated the development of interstitial fibrosis and glomerulosclerosis caused by puromycin (Tofovic et al. 2000). Finally, long-term treatment with caffeine reduced renal function and augmented proteinuria in obese diabetic ZSF1 rats despite improving glucose tolerance. Caffeine-induced renal deterioration was paralleled by enhanced fibrosis, proliferation, and inflammation (Tofovic et al. 2002; Tofovic et al. 2007). In addition to stimulating the release of renin, the effects of caffeine may be mediated through interference with the direct anti-inflammatory effects of adenosine (Tofovic et al. 2007).

In view of this solid body of evidence in support of caffeine as a risk factor in renal disease it is unexpected that the methylxanthine pentoxifylline has been found to produce exactly opposite outcomes. Pentoxifylline has only a low affinity for adenosine receptors and is generally considered a PDE inhibitor with some selectivity for PDE4 (Daly 2007). In animal studies, pentoxifylline markedly reduced the functional decline, proteinuria, fibrosis, and inflammation in rats following 5/6 nephrectomy or treatment with anti-GBM antiserum, and this was associated with an attenuation of the stimulated expression of mitogenic and profibrotic gene products (Chen et al. 2004; Lin et al. 2002). This effect was probably independent of the renin-angiotensin system since a combination of pentoxifylline with an ACE inhibitor further diminished disease progression (Lin et al. 2002), and since plasma renin was found to be unchanged in a human study (Chen et al. 2006). Furthermore, pentoxifylline protected against endotoxin-induced renal failure in mice and reduced plasma levels of TNF-alpha, Il-1beta, and nitric oxide (Wang et al. 2006). In relatively small human trials, pentoxifylline reduced proteinuria and slowed the GFR decline in patients with chronic renal failure (Lin et al. 2008; Perkins et al. 2009), and it reduced proteinuria in patients with primary glomerular diseases in association with a reduction of urinary MCP-1 excretion (Chen et al. 2006). In non-hypertensive type 2 diabetic subjects pentoxifylline was as effective in reducing microalbuminuria as the ACE inhibitor captopril (Rodriguez-Moran and Guerrero-Romero 2005). A meta-analysis of 10 randomized controlled studies in adult patients with diabetic kidney disease suggested comparable efficacies of pentoxifylline and captopril in reducing proteinuria (McCormick et al. 2008). The mechanism of action of the protective effects of pentoxifylline or its metabolite lisofylline is unclear.

\section{Radiocontrast nephropathy}

Iodinated radiocontrast agents used in a number of radiological imaging procedures can cause acute renal failure. The incidence is very low in the absence of complicating factors, but it increases considerably in patients with pre-existing renal conditions or in other circumstances that represent a risk factor for developing acute renal failure in general such as dehydration or low cardiac output. Since radiocontrast-induced renal failure is accompanied by a reduction of renal blood flow and glomerular filtration rate, methylxanthines have been among a number of vasodilator agents that have been assessed in regard to their preventive potential. In Na-depleted dogs, radiocontrast agents reduced renal blood flow and GFR, and both of these effects were attenuated by prior administration of theophylline (Arend et al. 1987; Deray et al. 1990). Furthermore, theophylline partially prevented the reduction of medullary blood flow induced by iodixanol (Lancelot et al. 2002). Thus, theophylline appears to act by antagonizing vasoconstriction mediated by A1 
adenosine receptor activation, and this hypothesis was corroborated in studies in which the A1 adenosine receptor selective antagonist KW-3902 was even more effective than theophylline in attenuating iohexol-induced renal functional impairment in dogs with preexisting renal insufficiency (Arakawa et al. 1996). Acute renal failure and cytotoxicity following iohexol were found to be more pronounced in wild type than in A1 adenosine receptor-deficient mice, and a similar protective effect could be seen when wild type mice were pretreated with the A1 adenosine receptor selective antagonist DPCPX (Lee et al. 2006). In rats pretreated chronically with L-NAME, but not in control rats, Na diatrizoate caused a decrease of GFR and RBF that could be fully prevented by pretreatment with theophylline, DPCPX, or KW-3902 (Erley et al. 1997; Yao et al. 2001). It could also be prevented by extracellular volume expansion, the standard preventive strategy (Yao et al. 2001). In the majority of studies, prophylactic administration of theophylline or aminophylline has also been reported to provide protection against radiocontrast renal failure in humans (Erley et al. 1994; Huber et al. 2001; Huber et al. 2003; Kapoor et al. 2002; Katholi et al. 1995; Kolonko et al. 1998). Protection by theophylline was similar to that afforded by oral or intravenous hydration (Erley et al. 1999). Two recent meta-analyses, one including 480 and the other 585 patients, conclude that theophylline or aminophylline appear to attenuate the radiocontrast-induced decline of renal function (Bagshaw and Ghali 2005; Ix et al. 2004). On the other hand, an analysis of 41 studies that used radiocontrast agents in combination with theophylline, $\mathrm{N}$-acetylcysteine, fenoldopam, dopamine, iloprost, statins, furosemide or mannitol showed that only $\mathrm{N}$-acetylcysteine provided significant renoprotection whereas the risk reduction provided by theophylline was not significant (Kelly et al. 2008). Greater protection by $\mathrm{N}$-acetylcysteine than by theophylline was also observed in a study in dehydrated rats (Efrati et al. 2009). Exactly how methylxanthines exert their limited protective effect is unclear in view of the well recognized multifactorial pathophysiology of radiocontrast-induced nephropathy (Cox and Tsikouris 2004; Persson et al. 2005). Because of similar effects of other vasoactive agents such as ANP, dopamine, endothelin antagonists, Ca channel blockers, and PGE2, non-specific vasodilatation of the renal vascular bed is likely to play a major contributory role. Nevertheless, despite some promising results the overall clinical experience does not support the use of methylxanthines as a first line defense against the induction of contrast nephropathy (Lin and Bonventre 2005).

\section{Calcineurin inhibitors}

The main complication of immunosuppression by calcineurin inhibitors is nephrotoxicity manifesting itself in a decline of renal function associated with vasoconstriction and a reduction of renal blood flow. In early studies in rats, theophylline failed to ameliorate cyclosporine-induced renal vasoconstriction indicating that it was not caused by adenosine (Churchill et al. 1990). Subsequently however, caffeine, theophylline, and pentoxifylline were observed to reduce the acute contractile response of isolated glomeruli and mesangial cells in culture to cyclosporine (Potier et al. 1997). Furthermore, the acute reduction of GFR and renal blood flow caused in rats by a single dose of tacrolimus was completely reversed by theophylline given 1 hour after the drug (McLaughlin et al. 2003a). Concomitant chronic administration of theophylline together with tacrolimus prevented the decrease of creatinine clearance that was caused by tacrolimus in the control group (McLaughlin et al. 2003b). In contrast, chronic administration of theophylline did not protect against cyclosporine-induced renal failure in rabbits and even enhanced its cytotoxic effects whereas functional recovery was seen when theophylline was given as a single dose following a 5 day treatment with cyclosporine (Prevot et al. 2002). Follow-up studies that would shed light on the reasons for these divergent observations are not available. In children with non-renal transplants which showed signs of tacrolimus nephrotoxicity such as an increase in serum creatinine and oliguria despite treatment with loop diuretics, a single dose of aminophylline $(5 \mathrm{mg} / \mathrm{kg})$ 
caused a doubling of urine flow rate and osmolar clearance as well as a moderate increase of renal function (McLaughlin and Abitbol 2005).

\section{Cisplatin}

Cisplatin-based chemotherapy is another treatment modality that is often associated with nephrotoxicity. In a placebo-controlled trial on 36 patients, the administration of theophylline before and for 5 days following cisplatin treatment completely prevented the fall of inulin clearance that was seen in the placebo group in which GFR fell by $21 \%$ (Benoehr et al. 2005). This study in humans thus is consistent with observations in rats in which aminophylline ameliorated cisplatin-induced renal failure when given in the maintenance phase although it did not prevent the decline of renal function when administered prophylactically (Heidemann et al. 1989). Since enprofylline did not mimick the protective action of aminophylline, adenosine receptor activation is the likely cause for the decline of renal function (Heidemann et al. 1989). Specifically, the protective action seems related to inhibition of A1 adenosine receptors because the A1 adenosine receptorspecific antagonists DPCPX and KW-3902 were effective both in preventing and treating the nephrotoxic effects of cisplatin (Knight et al. 1991; Nagashima et al. 1995). A higher dose of cisplatin in vivo as well as exposure of LLC-PK1 cells to cisplatin caused upregulation of A1 adenosine receptor expression, and this was associated with cytoprotection based on the finding that non-selective and $\mathrm{A} 1$ adenosine receptor-selective antagonists exacerbated cisplatin-induced nephrotoxicity (Bhat et al. 2002; Pingle et al. 2004; Saad et al. 2004). Thus, the potential of methylxanthines to exert both protective and injurious effects may be a reflection of the wide spectrum of adenosine actions in fundamental processes such as tissue oxygen supply and inflammation.

\section{Glycerol}

Theophylline and other methylxanthines have been consistently found to ameliorate the experimental acute renal failure caused by intramuscular injection of glycerol when treatment was started at the time of injury (Bidani and Churchill 1983; Bowmer et al. 1986, 1988). The protective effect appears to be a consequence of inhibition of $A 1$ adenosine receptors since subtype-specific antagonists mimick the action of the natural methylxanthines (Ishikawa et al. 1993; Panjehshahin et al. 1992; Suzuki et al. 1992) and since their effect can be seen in a dose range that have no discernible effect on renal phosphodiesterase activity (Panjehshahin et al. 1992). In contrast to the protective action of methylxanthines in myoglobinuric acute renal failure, theophylline did not improve renal function in the renal failure caused by mercury chloride or gentamicin (Kellett et al. 1988; Rossi et al. 1990).

\section{Ischemia-Reperfusion}

Interest in the potential of methylxanthines to improve renal function following postischemic acute renal failure (ARF) has arisen from the fact that ischemia is associated with increases of adenosine tissue content in the kidney as well as in other organs (Osswald et al. 1977). Thus, it was conceivable that methylxanthines may exert beneficial effects by preventing the renal vasoconstriction caused by excess adenosine. In rats, theophylline, administered as a single dose of $100 \mu \mathrm{mol} / \mathrm{kg} 10 \mathrm{~min}$ before the release of a 1 hour renal artery occlusion, increased GFR and electrolyte excretion 3-6-fold within 3 hours of the postischemic period compared to vehicle treated animals (Osswald et al. 1979), an observation that was later confirmed in both rats and rabbits (Gouyon and Guignard 1988; Lin et al. 1986). The protective mechanism of methylxanthines in the initiation phase of renal injury following ischemia-reperfusion is likely related at least in part to inhibition of vasoconstrictive adenosine receptors. Support for this notion comes from a recent study in which the A1 adenosine receptor antagonist DPCPX infused prior to and following a $30 \mathrm{~min}$ 
period of bilateral renal artery obstruction was observed to significantly improve creatinine clearance over the initial 4 hours following reperfusion (Moosavi et al. 2009). Furthermore, the immediate postischemic reduction of GFR was enhanced by dipyridamole, an inhibitor of adenosine uptake through equilibrative nucleoside transporters, and this effect was abrogated by theophylline (Lin et al. 1987). In clinical studies, a single dose of theophylline given early after birth in asphyxiated full-term infants elicited beneficial effects by reducing the renal involvement and fall in GFR as determined over the first 5 days (Bakr 2005; Bhat et al. 2006; Eslami et al. 2009; Jenik et al. 2000).

The role of methylxanthines in the maintenance phase following renal ischemia is an area of considerable controversy. Early studies have shown that pretreatment of rats with a single dose of theophylline during a 30 minute renal artery occlusion was associated with higher renal blood flow and GFR during the maintenance phase of ARF after 5 days suggesting that theophylline administration in the acute phase affected the severity of renal failure in the maintenance phase (Lin et al. 1988). Furthermore, theophylline administered 5 days after ischemia acutely increased renal blood flow and GFR in previously untreated rats (Lin et al. 1988). Theophylline also caused an increase of GFR measured 5 days after experimental renal transplantation in rats without affecting the inflammatory response (Grenz et al. 2006). On the other hand, in a small study with limited statistical power theophylline was not found to afford protection against acute renal failure during cardiac surgery (Kramer et al. 2002). It is uncertain whether theophylline exerts these effects by antagonizing vasoconstrictor effects of adenosine. In fact, adenosine itself given immediately after a renal ischemia of 45 minutes provided renoprotection after 24 hours, an effect mimicked by CGS-21680 and therefore apparently mediated by activation of A2a adenosine receptors (Lee and Emala 2001). Similarly, the rise of serum creatinine assessed 1 and 2 days following renal ischemia was found to be reduced by chronic administration of the selective A2a agonist DWH-146 and enhanced in A2a adenosine receptor-deficient mice (Day et al. 2003; Okusa et al. 1999). Relative renoprotection 24 hours following renal ischemia was also provided by A1 adenosine receptor agonists, and a worsening of the outcome was observed in A1 adenosine receptor-deficient mice (Kim et al. 2009; Lee et al. 2004a; Lee et al. 2004b). Comparable renoprotective effects of $\mathrm{A} 2 \mathrm{a}$ and $\mathrm{A} 1$ adenosine receptor activation suggest that the functional improvement after extended reperfusion is unrelated to the vascular actions of adenosine since the vascular effects of activating A2a or A1 adenosine receptors are opposite. The common denominator may be a dominant anti-inflammatory action of adenosine that is exerted by both receptor subtypes.

\section{References}

Andersson KE, Johannesson N, Karlberg B, Persson CG. Increase in plasma free fatty acids and natriuresis by xanthines may reflect adenosine antagonism. Eur J Clin Pharmacol. 1984; 26:33-38. [PubMed: 6370703]

Arakawa K, Suzuki H, Naitoh M, Matsumoto A, Hayashi K, Matsuda H, Ichihara A, Kubota E, Saruta T. Role of adenosine in the renal responses to contrast medium. Kidney Int. 1996; 49:1199-1206. [PubMed: 8731082]

Arend LJ, Bakris GL, Burnett JC Jr, Megerian C, Spielman WS. Role for intrarenal adenosine in the renal hemodynamic response to contrast media. J Lab Clin Med. 1987; 110:406-411. [PubMed: 3655519]

Armstrong LE. Caffeine, body fluid-electrolyte balance, and exercise performance. Int J Sport Nutr Exerc Metab. 2002; 12:189-206. [PubMed: 12187618]

Armstrong LE, Pumerantz AC, Roti MW, Judelson DA, Watson G, Dias JC, Sokmen B, Casa DJ, Maresh CM, Lieberman H, Kellogg M. Fluid, electrolyte, and renal indices of hydration during 11 days of controlled caffeine consumption. Int J Sport Nutr Exerc Metab. 2005; 15:252-265. [PubMed: 16131696] 
Baer PG, Armstrong EL, Cagen LM. Dissociation of effects of xanthine analogs on renal prostaglandins and renal excretory function in the awake rat. J Pharmacol Exp Ther. 1983; 227:600 604. [PubMed: 6581288]

Bagshaw SM, Ghali WA. Theophylline for prevention of contrast-induced nephropathy: a systematic review and meta-analysis. Arch Intern Med. 2005; 165:1087-1093. [PubMed: 15911721]

Bailey MA. Inhibition of bicarbonate reabsorption in the rat proximal tubule by activation of luminal P2Y1 receptors. Am J Physiol Renal Physiol. 2004; 287:F789-F796. [PubMed: 15172882]

Bakr AF. Prophylactic theophylline to prevent renal dysfunction in newborns exposed to perinatal asphyxia--a study in a developing country. Pediatr Nephrol. 2005; 20:1249-1252. [PubMed: 15947981]

Balakrishnan VS, Coles GA, Williams JD. A potential role for endogenous adenosine in control of human glomerular and tubular function. Am J Physiol. 1993; 265:F504-F510. [PubMed: 8238379]

Baranowski RL, Westenfelder C. Estimation of renal interstitial adenosine and purine metabolites by microdialysis. Am J Physiol. 1994; 267:F174-F182. [PubMed: 8048558]

Belibi FA, Wallace DP, Yamaguchi T, Christensen M, Reif G, Grantham JJ. The effect of caffeine on renal epithelial cells from patients with autosomal dominant polycystic kidney disease. J Am Soc Nephrol. 2002; 13:2723-2729. [PubMed: 12397042]

Benoehr P, Krueth P, Bokemeyer C, Grenz A, Osswald H, Hartmann JT. Nephroprotection by theophylline in patients with cisplatin chemotherapy: a randomized, single-blinded, placebocontrolled trial. J Am Soc Nephrol. 2005; 16:452-458. [PubMed: 15590762]

Beutler JJ, Koomans HA, Bijlsma JA, Dorhout Mees EJ. Renal actions of theophylline and atrial natriuretic peptide in humans: a comparison by means of clearance studies. J Pharmacol Exp Ther. 1990; 255:1314-1319. [PubMed: 2148189]

Bhat MA, Shah ZA, Makhdoomi MS, Mufti MH. Theophylline for renal function in term neonates with perinatal asphyxia: a randomized, placebo-controlled trial. J Pediatr. 2006; 149:180-184. [PubMed: 16887430]

Bhat SG, Mishra S, Mei Y, Nie Z, Whitworth CA, Rybak LP, Ramkumar V. Cisplatin up-regulates the adenosine A(1) receptor in the rat kidney. Eur J Pharmacol. 2002; 442:251-264. [PubMed: 12065079]

Bidani AK, Churchill PC. Aminophylline ameliorates glycerol-induced acute renal failure in rats. Can J Physiol Pharmacol. 1983; 61:567-571. [PubMed: 6883209]

Bowmer CJ, Collis MG, Yates MS. Effect of the adenosine antagonist 8-phenyltheophylline on glycerol-induced acute renal failure in the rat. Br J Pharmacol. 1986; 88:205-212. [PubMed: 3708216]

Bowmer CJ, Collis MG, Yates MS. Amelioration of glycerol-induced acute renal failure in the rat with 8-phenyltheophylline: timing of intervention. J Pharm Pharmacol. 1988; 40:733-735. [PubMed: 2907545]

Brater DC, Kaojarern S, Chennavasin P. Pharmacodynamics of the diuretic effects of aminophylline and acetazolamide alone and combined with furosemide in normal subjects. J Pharmacol Exp Ther. 1983; 227:92-97. [PubMed: 6620175]

Brown NJ, Porter J, Ryder D, Branch RA. Caffeine potentiates the renin response to diazoxide in man. Evidence for a regulatory role of endogenous adenosine. J Pharmacol Exp Ther. 1991; 256:56-61. [PubMed: 1988669]

Brown NJ, Ryder D, Nadeau J. Caffeine attenuates the renal vascular response to angiotensin II infusion. Hypertension. 1993; 22:847-852. [PubMed: 8244516]

Cai H, Batuman V, Puschett DB, Puschett JB. Effect of KW-3902, a novel adenosine A1 receptor antagonist, on sodium-dependent phosphate and glucose transport by the rat renal proximal tubular cell. Life Sci. 1994; 55:839-845. [PubMed: 8072380]

Cai H, Puschett DB, Guan S, Batuman V, Puschett JB. Phosphate transport inhibition by KW-3902, an adenosine A1 receptor antagonist, is mediated by cyclic adenosine monophosphate. Am J Kidney Dis. 1995; 26:825-830. [PubMed: 7485140]

Chen YM, Lin SL, Chiang WC, Wu KD, Tsai TJ. Pentoxifylline ameliorates proteinuria through suppression of renal monocyte chemoattractant protein-1 in patients with proteinuric primary glomerular diseases. Kidney Int. 2006; 69:1410-1455. [PubMed: 16541021] 
Chen YM, Ng YY, Lin SL, Chiang WC, Lan HY, Tsai TJ. Pentoxifylline suppresses renal tumour necrosis factor-alpha and ameliorates experimental crescentic glomerulonephritis in rats. Nephrol Dial Transplant. 2004; 19:1106-1115. [PubMed: 14993492]

Choi KC, Lee J, Moon KH, Park KK, Kim SW, Kim NH. Chronic caffeine ingestion exacerbates 2kidney, 1-clip hypertension and ameliorates deoxycorticosterone acetate-salt hypertension in rats. Nephron. 1993; 65:619-622. [PubMed: 8302420]

Churchill PC, Rossi NF, Churchill MC, Bidani AK, McDonald FD. Acute cyclosporine-induced renal vasoconstriction: lack of effect of theophylline. Am J Physiol. 1990; 258:F41-F45. [PubMed: 2301595]

Cirillo R, Grossi E, Franzone JS. Doxofylline, an adenosine-nonblocking xanthine, does not induce cardiostimulant effects. Res Commun Chem Pathol Pharmacol. 1989; 65:21-34. [PubMed: 2781149]

Coulson R, Johnson RA, Olsson RA, Cooper DR, Scheinman SJ. Adenosine stimulates phosphate and glucose transport in opossum kidney epithelial cells. Am J Physiol. 1991; 260:F921-F928. [PubMed: 1647692]

Coulson R, Proch PS, Olsson RA, Chalfant CE, Cooper DR. Upregulated renal adenosine A1 receptors augment PKC and glucose transport but inhibit proliferation. Am J Physiol. 1996; 270:F263-F274. [PubMed: 8779886]

Cox CD, Tsikouris JP. Preventing contrast nephropathy: what is the best strategy? A review of the literature. J Clin Pharmacol. 2004; 44:327-337. [PubMed: 15051739]

Daly JW. Caffeine analogs: biomedical impact. Cell Mol Life Sci. 2007; 64:2153-2169. [PubMed: 17514358]

Davis JO, Shock NW. The effect of theophylline ethylene diamine on renal function in control subjects and in patients with congestive heart failure. J Clin Invest. 1949; 28:1459-1468. [PubMed: 15395948]

Day YJ, Huang L, McDuffie MJ, Rosin DL, Ye H, Chen JF, Schwarzschild MA, Fink JS, Linden J, Okusa MD. Renal protection from ischemia mediated by A2A adenosine receptors on bone marrow-derived cells. J Clin Invest. 2003; 112:883-891. [PubMed: 12975473]

Deray G, Martinez F, Cacoub P, Baumelou B, Baumelou A, Jacobs C. A role for adenosine calcium and ischemia in radiocontrast-induced intrarenal vasoconstriction. Am J Nephrol. 1990; 10:316322. [PubMed: 2240059]

Di Sole F. Adenosine and renal tubular function. Curr Opin Nephrol Hypertens. 2008; 17:399-407. [PubMed: 18660677]

Di Sole F, Cerull R, Petzke S, Casavola V, Burckhardt G, Helmle-Kolb C. Bimodal acute effects of A1 adenosine receptor activation on $\mathrm{Na}+\mathrm{H}+$ exchanger 3 in opossum kidney cells. J Am Soc Nephrol. 2003; 14:1720-1730. [PubMed: 12819231]

Dinour D, Brezis M. Effects of adenosine on intrarenal oxygenation. Am J Physiol. 1991; 261:F787_ F791. [PubMed: 1951710]

Edwards RM, Spielman WS. Adenosine A1 receptor-mediated inhibition of vasopressin action in inner medullary collecting duct. Am J Physiol. 1994; 266:F791-F796. [PubMed: 8203563]

Efrati S, Berman S, Ilgiyeav I, Siman-Tov Y, Averbukh Z, Weissgarten J. Differential effects of Nacetylcysteine, theophylline or bicarbonate on contrast-induced rat renal vasoconstriction. Am J Nephrol. 2009; 29:181-191. [PubMed: 18781062]

Eggertsen R, Andreasson A, Hedner T, Karlberg BE, Hansson L. Effect of coffee on ambulatory blood pressure in patients with treated hypertension. J Intern Med. 1993; 233:351-355. [PubMed: 8463768]

Erley CM, Duda SH, Rehfuss D, Scholtes B, Bock J, Muller C, Osswald H, Risler T. Prevention of radiocontrast-media-induced nephropathy in patients with pre-existing renal insufficiency by hydration in combination with the adenosine antagonist theophylline. Nephrol Dial Transplant. 1999; 14:1146-1149. [PubMed: 10344353]

Erley CM, Duda SH, Schlepckow S, Koehler J, Huppert PE, Strohmaier WL, Bohle A, Risler T, Osswald $\mathrm{H}$. Adenosine antagonist theophylline prevents the reduction of glomerular filtration rate after contrast media application. Kidney Int. 1994; 45:1425-1431. [PubMed: 8072255] 
Erley CM, Heyne N, Burgert K, Langanke J, Risler T, Osswald H. Prevention of radiocontrast-induced nephropathy by adenosine antagonists in rats with chronic nitric oxide deficiency. J Am Soc Nephrol. 1997; 8:1125-1132. [PubMed: 9219162]

Eslami Z, Shajari A, Kheirandish M, Heidary A. Theophylline for prevention of kidney dysfunction in neonates with severe asphyxia. Iran J Kidney Dis. 2009; 3:222-226. [PubMed: 19841526]

Franco M, Bell PD, Navar LG. Effect of adenosine A1 analogue on tubuloglomerular feedback mechanism. Am J Physiol Renal Physiol. 1989; 257:F231-F236.

Franzone JS, Cirillo R, Barone D. Doxofylline and theophylline are xanthines with partly different mechanisms of action in animals. Drugs Exp Clin Res. 1988; 14:479-489. [PubMed: 3240706]

Fulgraff, G. Xanthinderivate als Diuretika. In: Herken, H., editor. Handbuch der Experimentellen Pharmakologie. Vol. vol XXIV. Berlin: Springer Verlag; 1969. p. 596-640.

Gerber JG, Nies AS. Renal vasoconstrictor response to hypertonic saline in the dog: effects of prostaglandins, indomethacin and theophylline. J Physiol (Lond). 1986; 380:35-43. [PubMed: 3302211]

Gerkens JF, Heidemann HT, Jackson EK, Branch RA. Aminophylline inhibits renal vasoconstriction produced by intrarenal hypertonic saline. J Pharmacol Exp Ther. 1983; 225:611-615. [PubMed: 6864522]

Gouyon JB, Guignard JP. Renal effects of theophylline and caffeine in newborn rabbits. Pediatr Res. 1987; 21:615-618. [PubMed: 3601478]

Gouyon JB, Guignard JP. Theophylline prevents the hypoxemia-induced renal hemodynamic changes in rabbits. Kidney Int. 1988; 33:1078-1083. [PubMed: 3404810]

Grandjean AC, Reimers KJ, Bannick KE, Haven MC. The effect of caffeinated, non-caffeinated, caloric and non-caloric beverages on hydration. J Am Coll Nutr. 2000; 19:591-600. [PubMed: 11022872]

Grantham JJ, Orloff J. Effect of prostaglandin E1 on the permeability response of the isolated collecting tubule to vasopressin, adenosine 3',5'-monophosphate, and theophylline. J Clin Invest. 1968; 47:1154-1161. [PubMed: 4296382]

Grenz A, Baier D, Petroktistis F, Wehrmann M, Kohle C, Schenk M, Sessler M, Gleiter CH, Fandrich $\mathrm{F}$, Osswald $\mathrm{H}$. Theophylline improves early allograft function in rat kidney transplantation. $\mathrm{J}$ Pharmacol Exp Ther. 2006; 317:473-479. [PubMed: 16410406]

Handler JS, Butcher RW, Sutherland EW, Orloff J. The effect of vasopressin and of theophylline on the concentration of adenosine 3',5'-phosphate in the urinary bladder of the toad. J Biol Chem. 1965; 240:4524-4526. [PubMed: 5845852]

Hedqvist P, Fredholm BB. Effects of adenosine on adrenergic neurotransmission; prejunctional inhibition and postjunctional enhancement. Naunyn Schmiedebergs Arch Pharmacol. 1976; 293:217-223. [PubMed: 183154]

Hedqvist P, Fredholm BB, Olundh S. Antagonistic effects of theophylline and adenosine on adrenergic neuroeffector transmission in the rabbit kidney. Circ Res. 1978; 43:592-598. [PubMed: 210977]

Heidemann HT, Muller S, Mertins L, Stepan G, Hoffmann K, Ohnhaus EE. Effect of aminophylline on cisplatin nephrotoxicity in the rat. Br J Pharmacol. 1989; 97:313-318. [PubMed: 2758217]

Huber W, Jeschke B, Page M, Weiss W, Salmhofer H, Schweigart U, Ilgmann K, Reichenberger J, Neu B, Classen M. Reduced incidence of radiocontrast-induced nephropathy in ICU patients under theophylline prophylaxis: a prospective comparison to series of patients at similar risk. Intensive Care Med. 2001; 27:1200-1209. [PubMed: 11534569]

Huber W, Schipek C, Ilgmann K, Page M, Hennig M, Wacker A, Schweigart U, Lutilsky L, Valina C, Seyfarth M, Schomig A, Classen M. Effectiveness of theophylline prophylaxis of renal impairment after coronary angiography in patients with chronic renal insufficiency. Am J Cardiol. 2003; 91:1157-1162. [PubMed: 12745095]

Ibarrola AM, Inscho EW, Vari RC, Navar LG. Influence of adenosine receptor blockade on renal function and renal autoregulation. J Am Soc Nephrol. 1991; 2:991-999. [PubMed: 1760542]

Ishikawa I, Shikura N, Takada K. Amelioration of glycerol-induced acute renal failure in rats by an adenosine A1 receptor antagonist (FR-113453). Ren Fail. 1993; 15:1-5. [PubMed: 8441832] 
Ishikawa SE, Okada K, Saito T. Modulation by intracellular calcium pool of arginine vasopressininduced cellular cyclic AMP production in rat renal papillary collecting tubule cells in culture. $\mathbf{J}$ Pharmacol Exp Ther. 1992; 263:1050-1055. [PubMed: 1335053]

Ix JH, McCulloch CE, Chertow GM. Theophylline for the prevention of radiocontrast nephropathy: a meta-analysis. Nephrol Dial Transplant. 2004; 19:2747-2753. [PubMed: 15328384]

Izzo JL Jr, Ghosal A, Kwong T, Freeman RB, Jaenike JR. Age and prior caffeine use alter the cardiovascular and adrenomedullary responses to oral caffeine. Am J Cardiol. 1983; 52:769-773. [PubMed: 6353897]

Jackson EK, Mi Z, Gillespie DG, Dubey RK. Metabolism of cAMP to adenosine in the renal vasculature. J Pharmacol Exp Ther. 1997; 283:177-182. [PubMed: 9336322]

Jenik AG, Ceriani Cernadas JM, Gorenstein A, Ramirez JA, Vain N, Armadans M, Ferraris JR. A randomized, double-blind, placebo-controlled trial of the effects of prophylactic theophylline on renal function in term neonates with perinatal asphyxia. Pediatrics. 2000; 105:E45. [PubMed: 10742366]

Kapoor A, Kumar S, Gulati S, Gambhir S, Sethi RS, Sinha N. The role of theophylline in contrastinduced nephropathy: a case-control study. Nephrol Dial Transplant. 2002; 17:1936-1941. [PubMed: 12401850]

Katholi RE, Taylor GJ, McCann WP, Woods WT Jr, Womack KA, McCoy CD, Katholi CR, Moses HW, Mishkel GJ, Lucore CL, et al. Nephrotoxicity from contrast media: attenuation with theophylline. Radiology. 1995; 195:17-22. [PubMed: 7892462]

Kawabata M, Ogawa T, Takabatake T. Control of rat glomerular microcirculation by juxtaglomerular adenosine A1 receptors. Kidney Int Suppl. 1998; 67:S228-S230. [PubMed: 9736300]

Kellett R, Bowmer CJ, Collis MG, Yates MS. Effect of alkylxanthines on gentamicin-induced acute renal failure in the rat. J Pharm Pharmacol. 1988; 40:849-854. [PubMed: 2907577]

Kelly AM, Dwamena B, Cronin P, Bernstein SJ, Carlos RC. Meta-analysis: effectiveness of drugs for preventing contrast-induced nephropathy. Ann Intern Med. 2008; 148:284-294. [PubMed: 18283206]

Kim M, Chen SW, Park SW, Kim M, D'Agati VD, Yang J, Lee HT. Kidney-specific reconstitution of the A1 adenosine receptor in A1 adenosine receptor knockout mice reduces renal ischemiareperfusion injury. Kidney Int. 2009; 75:809-823. [PubMed: 19190680]

Knight RJ, Bowmer CJ, Yates MS. The diuretic action of 8-cyclopentyl-1,3-dipropylxanthine, a selective A1 adenosine receptor antagonist. Br J Pharmacol. 1993; 109:271-277. [PubMed: 8495243]

Knight RJ, Collis MG, Yates MS, Bowmer CJ. Amelioration of cisplatin-induced acute renal failure with 8-cyclopentyl-1,3-dipropylxanthine. Br J Pharmacol. 1991; 104:1062-1068. [PubMed: 1810593]

Kolonko A, Wiecek A, Kokot F. The nonselective adenosine antagonist theophylline does prevent renal dysfunction induced by radiographic contrast agents. J Nephrol. 1998; 11:151-156. [PubMed: 9650124]

Koschlakoff DJ. Beobachtungen ueber die Wirkung des citronensauren Coffeins. Virchow's Arch. Path. Anat. 1864; 31:436-445.

Kost CK Jr, Herzer WA, Rominski BR, Mi Z, Jackson EK. Diuretic response to adenosine A(1) receptor blockade in normotensive and spontaneously hypertensive rats: role of pertussis toxinsensitive G-proteins. J Pharmacol Exp Ther. 2000; 292:752-760. [PubMed: 10640315]

Kost CK Jr, Li P, Pfeifer CA, Jackson EK. Telemetric blood pressure monitoring in benign 2-kidney, 1-clip renovascular hypertension: effect of chronic caffeine ingestion. J Pharmacol Exp Ther. 1994; 270:1063-1070. [PubMed: 7932154]

Kramer BK, Preuner J, Ebenburger A, Kaiser M, Bergner U, Eilles C, Kammerl MC, Riegger GA, Birnbaum DE. Lack of renoprotective effect of theophylline during aortocoronary bypass surgery. Nephrol Dial Transplant. 2002; 17:910-915. [PubMed: 11981083]

Lancelot E, Idee JM, Lacledere C, Santus R, Corot C. Effects of two dimeric iodinated contrast media on renal medullary blood perfusion and oxygenation in dogs. Invest Radiol. 2002; 37:368-375. [PubMed: 12068157] 
Langard O, Holdaas H, Eide I, Kiil F. Conditions for augmentation of renin release by theophylline. Scand J Clin Lab Invest. 1983; 43:9-14. [PubMed: 6312554]

Lee HT, Emala CW. Systemic adenosine given after ischemia protects renal function via A(2a) adenosine receptor activation. Am J Kidney Dis. 2001; 38:610-618. [PubMed: 11532695]

Lee HT, Gallos G, Nasr SH, Emala CW. A1 adenosine receptor activation inhibits inflammation, necrosis, and apoptosis after renal ischemia-reperfusion injury in mice. J Am Soc Nephrol. 2004a; 15:102-111. [PubMed: 14694162]

Lee HT, Jan M, Bae SC, Joo JD, Goubaeva FR, Yang J, Kim M. A1 adenosine receptor knockout mice are protected against acute radiocontrast nephropathy in vivo. Am J Physiol Renal Physiol. 2006; 290:F1367-F1375. [PubMed: 16418301]

Lee HT, Xu H, Nasr SH, Schnermann J, Emala CW. A1 adenosine receptor knockout mice exhibit increased renal injury following ischemia and reperfusion. Am J Physiol Renal Physiol. 2004b; 286:F298-F306. [PubMed: 14600029]

Lee J, Ha JH, Kim S, Oh Y, Kim SW. Caffeine decreases the expression of Na+/K+-ATPase and the type $3 \mathrm{Na}+/ \mathrm{H}+$ exchanger in rat kidney. Clin Exp Pharmacol Physiol. 2002; 29:559-563. [PubMed: 12060097]

Lin J, Bonventre JV. Prevention of radiocontrast nephropathy. Curr Opin Nephrol Hypertens. 2005; 14:105-110. [PubMed: 15687835]

Lin JJ, Churchill PC, Bidani AK. Effect of theophylline on the initiation phase of postischemic acute renal failure in rats. J Lab Clin Med. 1986; 108:150-154. [PubMed: 3734588]

Lin JJ, Churchill PC, Bidani AK. The effect of dipyridamole on the initiation phase of postischemic acute renal failure in rats. Can J Physiol Pharmacol. 1987; 65:1491-1495. [PubMed: 3664362]

Lin JJ, Churchill PC, Bidani AK. Theophylline in rats during maintenance phase of post-ischemic acute renal failure. Kidney Int. 1988; 33:24-28. [PubMed: 3352158]

Lin SL, Chen YM, Chiang WC, Wu KD, Tsai TJ. Effect of pentoxifylline in addition to losartan on proteinuria and GFR in CKD: a 12-month randomized trial. Am J Kidney Dis. 2008; 52:464-474. [PubMed: 18617301]

Lin SL, Chen YM, Chien CT, Chiang WC, Tsai CC, Tsai TJ. Pentoxifylline attenuated the renal disease progression in rats with remnant kidney. J Am Soc Nephrol. 2002; 13:2916-2929. [PubMed: 12444210]

Ludens JH, Willis LR, Williamson HE. The effect of aminophylline on renal hemodynamics and sodium excretion. Arch Int Pharmacodyn Ther. 1970; 185:274-286. [PubMed: 5473790]

Massey LK, Bergman EA, Wise KJ, Sherrard DJ. Interactions between dietary caffeine and calcium on calcium and bone metabolism in older women. J Am Coll Nutr. 1994; 13:592-596. [PubMed: 7706592]

Mazkereth R, Laufer J, Jordan S, Pomerance JJ, Boichis H, Reichman B. Effects of theophylline on renal function in premature infants. Am J Perinatol. 1997; 14:45-49. [PubMed: 9259896]

McCormick BB, Sydor A, Akbari A, Fergusson D, Doucette S, Knoll G. The effect of pentoxifylline on proteinuria in diabetic kidney disease: a meta-analysis. Am J Kidney Dis. 2008; 52:454-463. [PubMed: 18433957]

McLaughlin GE, Abitbol CL. Reversal of oliguric tacrolimus nephrotoxicity in children. Nephrol Dial Transplant. 2005; 20:1471-1475. [PubMed: 15840666]

McLaughlin GE, Kashimawo LA, Steele BW, Kuluz JW. Reversal of acute tacrolimus-induced renal vasoconstriction by theophylline in rats. Pediatr Crit Care Med. 2003a; 4:358-362. [PubMed: 12831420]

McLaughlin GE, Schober M, Perez M, Ruiz P, Steele BW, Abitbol C. Benefit of theophylline administration in tacrolimus-induced nephrotoxicity in rats. Pediatr Nephrol. 2003b; 18:860-864. [PubMed: 12836095]

Mi Z, Herzer WA, Zhang Y, Jackson EK. 3-isobutyl-1-methylxanthine decreases renal cortical interstitial levels of adenosine and inosine. Life Sci. 1994; 54:277-282. [PubMed: 7512185]

Mizumoto H, Karasawa A. Renal tubular site of action of KW-3902, a novel adenosine A1-receptor antagonist, in anesthetized rats. Jpn J Pharmacol. 1993; 61:251-253. [PubMed: 8483302] 
Moosavi SM, Bayat G, Owji SM, Panjehshahin MR. Early renal post-ischaemic tissue damage and dysfunction with contribution of A1-adenosine receptor activation in rat. Nephrology (Carlton). 2009; 14:179-188. [PubMed: 19207864]

Nagashima K, Kusaka H, Karasawa A. Protective effects of KW-3902, an adenosine A1-receptor antagonist, against cisplatin-induced acute renal failure in rats. Jpn J Pharmacol. 1995; 67:349357. [PubMed: 7650867]

Nauli SM, Alenghat FJ, Luo Y, Williams E, Vassilev P, Li X, Elia AE, Lu W, Brown EM, Quinn SJ, Ingber DE, Zhou J. Polycystins 1 and 2 mediate mechanosensation in the primary cilium of kidney cells. Nat Genet. 2003; 33:129-137. [PubMed: 12514735]

Neuhauser B, Beine S, Verwied SC, Luhrmann PM. Coffee consumption and total body water homeostasis as measured by fluid balance and bioelectrical impedance analysis. Ann Nutr Metab. 1997; 41:29-36. [PubMed: 9194998]

Nishiyama A, Kimura S, He H, Miura K, Rahman M, Fujisawa Y, Fukui T, Abe Y. Renal interstitial adenosine metabolism during ischemia in dogs. Am J Physiol Renal Physiol. 2001; 280:F231F238. [PubMed: 11208598]

Nussberger J, Mooser V, Maridor G, Juillerat L, Waeber B, Brunner HR. Caffeine-induced diuresis and atrial natriuretic peptides. J Cardiovasc Pharmacol. 1990; 15:685-691. [PubMed: 1692926]

Ohnishi A, Branch RA, Jackson K, Hamilton R, Biaggioni I, Deray G, Jackson EK. Chronic caffeine administration exacerbates renovascular, but not genetic, hypertension in rats. J Clin Invest. 1986; 78:1045-1050. [PubMed: 3020089]

Okusa MD, Linden J, Macdonald T, Huang L. Selective A2A adenosine receptor activation reduces ischemia-reperfusion injury in rat kidney. Am J Physiol. 1999; 277:F404-F412. [PubMed: 10484524]

Oliw E, Anggard E, Fredholm BB. Effect of indomethacin on the renal actions of theophylline. Eur J Pharmacol. 1977; 43:9-16. [PubMed: 193697]

Onrot J, Goldberg MR, Biaggioni I, Hollister AS, Kingaid D, Robertson D. Hemodynamic and humoral effects of caffeine in autonomic failure. Therapeutic implications for postprandial hypotension. N Engl J Med. 1985; 313:549-554. [PubMed: 3894971]

Orloff J, Handler JS. The similarity of effects of vasopressin, adenosine-3',5'-phosphate (cyclic AMP) and theophylline on the toad bladder. J Clin Invest. 1962; 41:702-709. [PubMed: 14482265]

Osswald H. Renal effects of adenosine and their inhibition by theophylline in dogs. NaunynSchmiedeberg Arch. Pharmacol. 1975; 288:79-86.

Osswald H, Helmlinger J, Jendralski A, Abrar B. Improvement of renal function by theophylline in acute renal failure of the rat. Naunyn-Schmiedebergs Arch. Pharmacol. 1979; 307 Suppl:R47. (abstract).

Osswald H, Nabakowski G, Hermes H. Adenosine as a possible mediator of metabolic control of glomerular filtration rate. Int J Biochem. 1980; 12:263-267. [PubMed: 7399032]

Osswald H, Schmitz HJ, Kemper R. Tissue content of adenosine, inosine and hypoxanthine in the rat kidney after ischemia and postischemic recirculation. Pflugers Arch. 1977; 371:45-49. [PubMed: 563575]

Palatini P, Canali C, Graniero GR, Rossi G, de Toni R, Santonastaso M, dal Follo M, Zanata G, Ferrarese E, Mormino P, Pessina AC. Relationship of plasma renin activity with caffeine intake and physical training in mild hypertensive men. HARVEST Study Group. Eur J Epidemiol. 1996; 12:485-491. [PubMed: 8905310]

Panjehshahin MR, Munsey TS, Collis MG, Bowmer CJ, Yates MS. Further characterization of the protective effect of 8-cyclopentyl-1,3-dipropylxanthine on glycerol-induced acute renal failure in the rat. J Pharm Pharmacol. 1992; 44:109-113. [PubMed: 1352809]

Passmore AP, Kondowe GB, Johnston GD. Renal and cardiovascular effects of caffeine: a doseresponse study. Clin Sci (Lond). 1987; 72:749-756. [PubMed: 3297472]

Paul S, Jackson EK, Robertson D, Branch RA, Biaggioni I. Caffeine potentiates the renin response to furosemide in rats. Evidence for a regulatory role of endogenous adenosine. J Pharmacol Exp Ther. 1989; 251:183-187. [PubMed: 2677316]

Pawlowska D, Granger JP, Knox FG. Effects of adenosine infusion into renal interstitium on renal hemodynamics. Am J Physiol. 1987; 252:F678-F682. [PubMed: 3565578] 
Perkins RM, Aboudara MC, Uy AL, Olson SW, Cushner HM, Yuan CM. Effect of pentoxifylline on GFR decline in CKD: a pilot, double-blind, randomized, placebo-controlled trial. Am J Kidney Dis. 2009; 53:606-616. [PubMed: 19216016]

Persson PB, Hansell P, Liss P. Pathophysiology of contrast medium-induced nephropathy. Kidney Int. 2005; 68:14-22. [PubMed: 15954892]

Pfeifer CA, Suzuki F, Jackson EK. Selective A1 adenosine receptor antagonism augments betaadrenergic-induced renin release in vivo. Am J Physiol. 1995; 269:F469-F479. [PubMed: 7485531]

Pingle SC, Mishra S, Marcuzzi A, Bhat SG, Sekino Y, Rybak LP, Ramkumar V. Osmotic diuretics induce adenosine A1 receptor expression and protect renal proximal tubular epithelial cells against cisplatin-mediated apoptosis. J Biol Chem. 2004; 279:43157-43167. [PubMed: 15272017]

Potier M, Aparicio M, Cambar J. Protective effect of three xanthine derivatives (theophylline, caffeine and pentoxifylline) against the cyclosporin A-induced glomerular contraction in isolated glomeruli and cultured mesangial cells. Nephron. 1997; 77:427-434. [PubMed: 9434065]

Premen AJ, Hall JE, Mizelle HL, Cornell JE. Maintenance of renal autoregulation during infusion of aminophylline or adenosine. Am J Physiol. 1985; 248:F366-F373. [PubMed: 2983569]

Prevot A, Liet JM, Semama DS, Justrabo E, Guignard JP, Gouyon JB. Disparate effects of chronic and acute theophylline on cyclosporine A nephrotoxicity. Pediatr Nephrol. 2002; 17:418-424. [PubMed: 12107806]

Rachima-Maoz C, Peleg E, Rosenthal T. The effect of caffeine on ambulatory blood pressure in hypertensive patients. Am J Hypertens. 1998; 11:1426-1432. [PubMed: 9880124]

Rakic V, Burke V, Beilin LJ. Effects of coffee on ambulatory blood pressure in older men and women: A randomized controlled trial. Hypertension. 1999; 33:869-873. [PubMed: 10082501]

Reid IA, Stockigt JR, Goldfien A, Ganong WF. Stimulation of renin secretion in dogs by theophylline. Eur J Pharmacol. 1972; 17:325-332. [PubMed: 4401810]

Ren Y, Arima S, Carretero OA, Ito S. Possible role of adenosine in macula densa control of glomerular hemodynamics. Kidney Int. 2002; 61:169-176. [PubMed: 11786098]

Rieg T, Steigele H, Schnermann J, Richter K, Osswald H, Vallon V. Requirement of intact adenosine A1 receptors for the diuretic and natriuretic action of the methylxanthines theophylline and caffeine. J Pharmacol Exp Ther. 2005; 313:403-409. [PubMed: 15590766]

Riesenhuber A, Boehm M, Posch M, Aufricht C. Diuretic potential of energy drinks. Amino Acids. 2006; 31:81-83. [PubMed: 16847703]

Robertson D, Frolich JC, Carr RK, Watson JT, Hollifield JW, Shand DG, Oates JA. Effects of caffeine on plasma renin activity, catecholamines and blood pressure. N Engl J Med. 1978; 298:181-186. [PubMed: 339084]

Robertson D, Hollister AS, Kincaid D, Workman R, Goldberg MR, Tung CS, Smith B. Caffeine and hypertension. Am J Med. 1984; 77:54-60. [PubMed: 6377891]

Rodriguez-Moran M, Guerrero-Romero F. Pentoxifylline is as effective as captopril in the reduction of microalbuminuria in non-hypertensive type 2 diabetic patients--a randomized, equivalent trial. Clin Nephrol. 2005; 64:91-97. [PubMed: 16114784]

Rossi N, Ellis V, Kontry T, Gunther S, Churchill P, Bidani A. The role of adenosine in $\mathrm{HgCl}$ 2-induced acute renal failure in rats. Am J Physiol. 1990; 258:F1554-F1560. [PubMed: 2360654]

Saad SY, Najjar TA, Alashari M. Role of non-selective adenosine receptor blockade and phosphodiesterase inhibition in cisplatin-induced nephrogonadal toxicity in rats. Clin Exp Pharmacol Physiol. 2004; 31:862-867. [PubMed: 15659050]

Schnermann J, Osswald H, Hermle M. Inhibitory effect of methylxanthines on feedback control of glomerular filtration rate in the rat. Pflugers Arch. 1977; 369:39-48. [PubMed: 195269]

Schnermann J, Weihprecht H, Briggs JP. Inhibition of tubuloglomerular feedback during adenosine1 receptor blockade. Am J Physiol Renal Physiol. 1990; 258:F553-F561.

Scott D, Rycroft JA, Aspen J, Chapman C, Brown B. The effect of drinking tea at high altitude on hydration status and mood. Eur J Appl Physiol. 2004; 91:493-498. [PubMed: 14872247]

Seideman P, Sollevi A, Fredholm BB. Additive renal effects of indomethacin and dipyridamole in man. Br J Clin Pharmacol. 1987; 23:323-330. [PubMed: 3567047] 
Shirley DG, Walter SJ, Noormohamed FH. Natriuretic effect of caffeine: assessment of segmental sodium reabsorption in humans. Clin Sci (Lond). 2002; 103:461-466. [PubMed: 12401118]

Siragy HM, Linden J. Sodium intake markedly alters renal interstitial fluid adenosine. Hypertension. 1996; 27:404-407. [PubMed: 8698445]

Smits P, Hoffmann H, Thien T, Houben H, van't Laar A. Hemodynamic and humoral effects of coffee after beta 1-selective and nonselective beta-blockade. Clin Pharmacol Ther. 1983; 34:153-158. [PubMed: 6347498]

Spielman WS. Antagonistic effect of theophylline on the adenosine-induced decreased in renin release. Am J Physiol. 1984; 247:F246-F251. [PubMed: 6087679]

Suzuki F, Shimada J, Mizumoto H, Karasawa A, Kubo K, Nonaka H, Ishii A, Kawakita T. Adenosine A1 antagonists. 2. Structure-activity relationships on diuretic activities and protective effects against acute renal failure. J Med Chem. 1992; 35:3066-3075. [PubMed: 1501234]

Takeda M, Yoshitomi K, Imai M. Regulation of Na(+)-3HCO3- cotransport in rabbit proximal convoluted tubule via adenosine A1 receptor. Am J Physiol. 1993; 265:F511-F519. [PubMed: 8238380]

Tanner GA, Tanner JA. Chronic caffeine consumption exacerbates hypertension in rats with polycystic kidney disease. Am J Kidney Dis. 2001; 38:1089-1095. [PubMed: 11684564]

Thomson S, Bao D, Deng A, Vallon V. Adenosine formed by 5'-nucleotidase mediates tubuloglomerular feedback. J Clin Invest. 2000; 106:289-298. [PubMed: 10903345]

Tofovic SP, Branch KR, Oliver RD, Magee WD, Jackson EK. Caffeine potentiates vasodilatorinduced renin release. J Pharmacol Exp Ther. 1991; 256:850-860. [PubMed: 2005584]

Tofovic SP, Jackson EK. Effects of long-term caffeine consumption on renal function in spontaneously hypertensive heart failure prone rats. J Cardiovasc Pharmacol. 1999; 33:360-366. [PubMed: 10069669]

Tofovic SP, Kost CK Jr, Jackson EK, Bastacky SI. Long-term caffeine consumption exacerbates renal failure in obese, diabetic, ZSF1 (fa-fa(cp)) rats. Kidney Int. 2002; 61:1433-1444. [PubMed: 11918750]

Tofovic SP, Kusaka H, Rominski B, Jackson EK. Caffeine increases renal renin secretion in a rat model of genetic heart failure. J Cardiovasc Pharmacol. 1999; 33:440-450. [PubMed: 10069681]

Tofovic SP, Rominski BR, Bastacky S, Jackso EK, Kost CK Jr. Caffeine augments proteinuria in puromycin-aminonucleoside nephrotic rats. Ren Fail. 2000; 22:159-179. [PubMed: 10803761]

Tofovic SP, Salah EM, Jackson EK, Melhem M. Early renal injury induced by caffeine consumption in obese, diabetic ZSF1 rats. Ren Fail. 2007; 29:891-902. [PubMed: 17994459]

Tseng CJ, Kuan CJ, Chu H, Tung CS. Effect of caffeine treatment on plasma renin activity and angiotensin I concentrations in rats on a low sodium diet. Life Sci. 1993; 52:883-890. [PubMed: 8445983]

Wang W, Zolty E, Falk S, Basava V, Reznikov L, Schrier R. Pentoxifylline protects against endotoxininduced acute renal failure in mice. Am J Physiol Renal Physiol. 2006; 291:F1090-F1095. [PubMed: 16985210]

Weihprecht H, Lorenz JN, Schnermann J, Skott O, Briggs JP. Effect of adenosine1-receptor blockade on renin release from rabbit isolated perfused juxtaglomerular apparatus. J Clin Invest. 1990; 85:1622-1628. [PubMed: 2185276]

Wemple RD, Lamb DR, McKeever KH. Caffeine vs caffeine-free sports drinks: effects on urine production at rest and during prolonged exercise. Int J Sports Med. 1997; 18:40-46. [PubMed: 9059904]

Wilcox CS, Welch WJ, Schreiner GF, Belardinelli L. Natriuretic and diuretic actions of a highly selective adenosine A1 receptor antagonist. J. Am Soc. Nephrol. 1999:714-720. [PubMed: 10203354]

Wise KJ, Bergman EA, Sherrard DJ, Massey LK. Interactions between dietary calcium and caffeine consumption on calcium metabolism in hypertensive humans. Am J Hypertens. 1996; 9:223-229. [PubMed: 8695020]

Yagil Y. Interaction of adenosine with vasopressin in the inner medullary collecting duct. Am J Physiol. 1990; 259:F679-F687. [PubMed: 2171361] 
Yao K, Heyne N, Erley CM, Risler T, Osswald H. The selective adenosine A1 receptor antagonist KW-3902 prevents radiocontrast media-induced nephropathy in rats with chronic nitric oxide deficiency. Eur J Pharmacol. 2001; 414:99-104. [PubMed: 11231000]

Yoneda $\mathrm{H}$, Hisa $\mathrm{H}$, Satoh S. Effects of adenosine on adrenergically induced renal vasoconstriction in dogs. Eur J Pharmacol. 1990; 176:109-116. [PubMed: 2311662]

Zou AP, Wu F, Li PL, Cowley AW Jr. Effect of chronic salt loading on adenosine metabolism and receptor expression in renal cortex and medulla in rats. Hypertension. 1999; 33:511-516.

[PubMed: 9931157] 